University of Nebraska - Lincoln

DigitalCommons@University of Nebraska - Lincoln

USDA National Wildlife Research Center - Staff Publications
U.S. Department of Agriculture: Animal and Plant Health Inspection Service

April 2005

\title{
Proximal cues of pocket gopher burrow plugging behavior: Influence of light, burrow openings, and temperature
}

\author{
Scott J. Werner \\ Utah State University, scott.j.werner@aphis.usda.gov \\ Dale L. Nolte \\ USDA-APHIS-Wildlife Services, Dale.L.Nolte@aphis.usda.gov \\ Frederick D. Provenza \\ Utah State University
}

Follow this and additional works at: https://digitalcommons.unl.edu/icwdm_usdanwrc

Part of the Environmental Sciences Commons

Werner, Scott J.; Nolte, Dale L.; and Provenza, Frederick D., "Proximal cues of pocket gopher burrow plugging behavior: Influence of light, burrow openings, and temperature" (2005). USDA National Wildlife Research Center - Staff Publications. 58.

https://digitalcommons.unl.edu/icwdm_usdanwrc/58

This Article is brought to you for free and open access by the U.S. Department of Agriculture: Animal and Plant Health Inspection Service at DigitalCommons@University of Nebraska - Lincoln. It has been accepted for inclusion in USDA National Wildlife Research Center - Staff Publications by an authorized administrator of DigitalCommons@University of Nebraska - Lincoln. 


\title{
Proximal cues of pocket gopher burrow plugging behavior: Influence of light, burrow openings, and temperature
}

\author{
Scott J. Werner, ${ }^{\mathrm{a}, *}$, Dale L. Nolte ${ }^{\mathrm{b}}$, Frederick D. Provenza ${ }^{\mathrm{a}}$

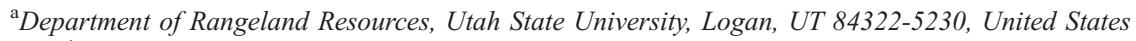 \\ ${ }^{\mathrm{b}}$ USDA/APHIS/WS/National Wildlife Research Center, Olympia, WA 98512, United States
}

Received 30 January 2003; accepted 27 April 2005

\begin{abstract}
Burrow plugging is readily observed among mammals adapted for digging (i.e., fossorial mammals) as they create and maintain their burrows. We investigated the influence of light, burrow openings, and thermal environment as cues of pocket gopher (Thomomys mazama, Thomomys talpoides) behavior. When given free access to light and no light during artificial-burrow preference trials, both Thomomys spp. consistently plugged (i.e., avoided) light treatments. Burrow openings did not notably affect plugging behavior of $T$. mazama. Gophers ( $T$. talpoides ) plugged the artificial burrows within the light and cold $\left(7^{\circ} \mathrm{C}\right)$ treatments, but not within the no-light, and 18 or $31{ }^{\circ} \mathrm{C}$ treatments when light and temperature were varied independently. Whereas the presence of light and low ambient temperatures induce burrow maintenance by pocket gophers, these cues help meliorate adverse conditions within subsurface environs.
\end{abstract}

(C) 2005 Elsevier Inc. All rights reserved.

Keywords: Behavioral cues; Fossorial; Habitat preference; Thermal ecology; Thomomys mazama; Thomomys talpoides

\section{Introduction}

Behavioral processes such as food and habitat selection operate via feedback in which animals exert control over aspects of their abiotic (e.g., temperature, light) and biotic environments (e.g., nutrients, competition, predation). In turn, resource dynamics and an individual's experience with specific foods and places affect subsequent behavior (e.g., foraging and burrowing among fossorial mammals). Despite the extensive literature regarding the biology and natural history of pocket gophers, few preference trials have been conducted to discern the environmental cues relevant to these fossorial herbivores. Rather, most studies regarding pocket gopher habitat relationships have correlated environmental parameters (e.g., ambient temperature and light) with

\footnotetext{
* Corresponding author. USDA/APHIS/WS/National Wildlife Research Center, 4101 LaPorte Avenue, Fort Collins, CO 80521, United States. Tel.: +1970266 6133; fax: +1 9702666138 .

E-mail address: Scott.J.Werner@aphis.usda.gov (S.J. Werner).
}

observed gopher activity (i.e., habitat selection, gopher movements, trapping success).

Pocket gopher herbivory and burrowing are associated with specific landscape features and sensory experiences [1]. Whereas burrowing likely meliorates adverse conditions within subsurface environments, some behavioral cues may induce burrow maintenance. Soil temperature, food availability, and/or seasonal activities (e.g., mating) have been previously hypothesized to affect the rate of earthen plug formation by pocket gophers [2]. Our experiments were designed to evaluate the influence of light, burrow openings, and temperature on the burrowing behavior of pocket gophers (Thomomys mazama, Thomomys talpoides).

Substrate transport among pocket gophers can be observed via earth plugs and terrestrial mounds. Earthen plugs are holes that have been filled with soil by gophers returning from the surface to their underground burrow system [3]. We have also observed gophers plugging (i.e., rejecting) particular areas within artificial and natural burrows to exclude used fecal chambers and human disturbance. Thus, in contrast to investigating habitat 
selection, we observed gophers plugging within artificial burrow systems to isolate occupied portions of the burrow from areas associated with avoided environmental stimuli.

\section{Materials and methods}

\subsection{Experiment 1}

This experiment was conducted at the Washington Field Station of the National Wildlife Research Center in Olympia, WA (USA). Experiment 1 was designed to test the influence of light and burrow openings on pocket gopher plugging behavior. This experiment was a two-by-two factorial, randomized block design with the presence and absence of light and burrow openings (Fig. 1a).

Twenty-four pocket gophers (T. mazama) were placed individually within an artificial burrow system for $12 \mathrm{~h}$ $(0730-1930 \mathrm{~h})$. The system was a 10-m network of 7-cmdiameter, clear polyvinyl chloride (PVC) pipe with a food cache and nest box (Fig. 1a). Food (ca. 50 g cut apples and 40 g Mazuri Rodent Pellets, PMI Feeds, Inc., St. Louis, MO) and water were available in the food cache at one end of the artificial burrow system. Each system treatment consisted of a 1-m-long loop (ca. $25 \mathrm{~cm}$ wide) of clear PVC pipe. The light treatment was enabled by the penetration of sunlight through the clear PVC of the artificial burrow. Sunlight was blocked by covering the no-light treatments of the system with approximately $12 \mathrm{~cm}$ of dry sawdust. Burrow openings (i.e., three openings per system treatment) were created by cutting a 0.5 -cm-wide semi-circle in the distal end of each burrow opening treatment within the system.

Approximately $1 \mathrm{~cm}$ of dry sawdust (plugging substrate) was uniformly placed throughout the inner surface of the artificial burrow system. The length of all plugs (i.e., complete obstruction of the inner surface of the artificial burrow) was measured to the nearest centimeter to account for gopher plugging in each burrow treatment following the 12-h trial. Burrow plugs in the midline of the artificial burrow system were not considered for data analysis; only plugs within system treatments were analyzed. All system treatments were cleaned, and sawdust was redistributed and/ or replaced between each trial to minimize inter-subject contamination of the artificial system.

The analysis of variance (ANOVA) procedure of the Statistical Analysis System (SAS) was used to analyze the factorial, randomized block design of Experiment 1. Tukey post-hoc contrasts were used to separate the means of significant $(P \leq 0.1)$ ANOVA effects (excluding animal replicates).

\subsection{Experiment 2}

This experiment was conducted at the Green Canyon Ecology Center, Utah State University in Logan, UT (USA). Experiment 2 was designed to test the influence of burrow temperature, and the presence and absence of light on pocket gopher plugging behavior. This experiment was a two-by-three factorial, randomized block design (Fig. 1b).
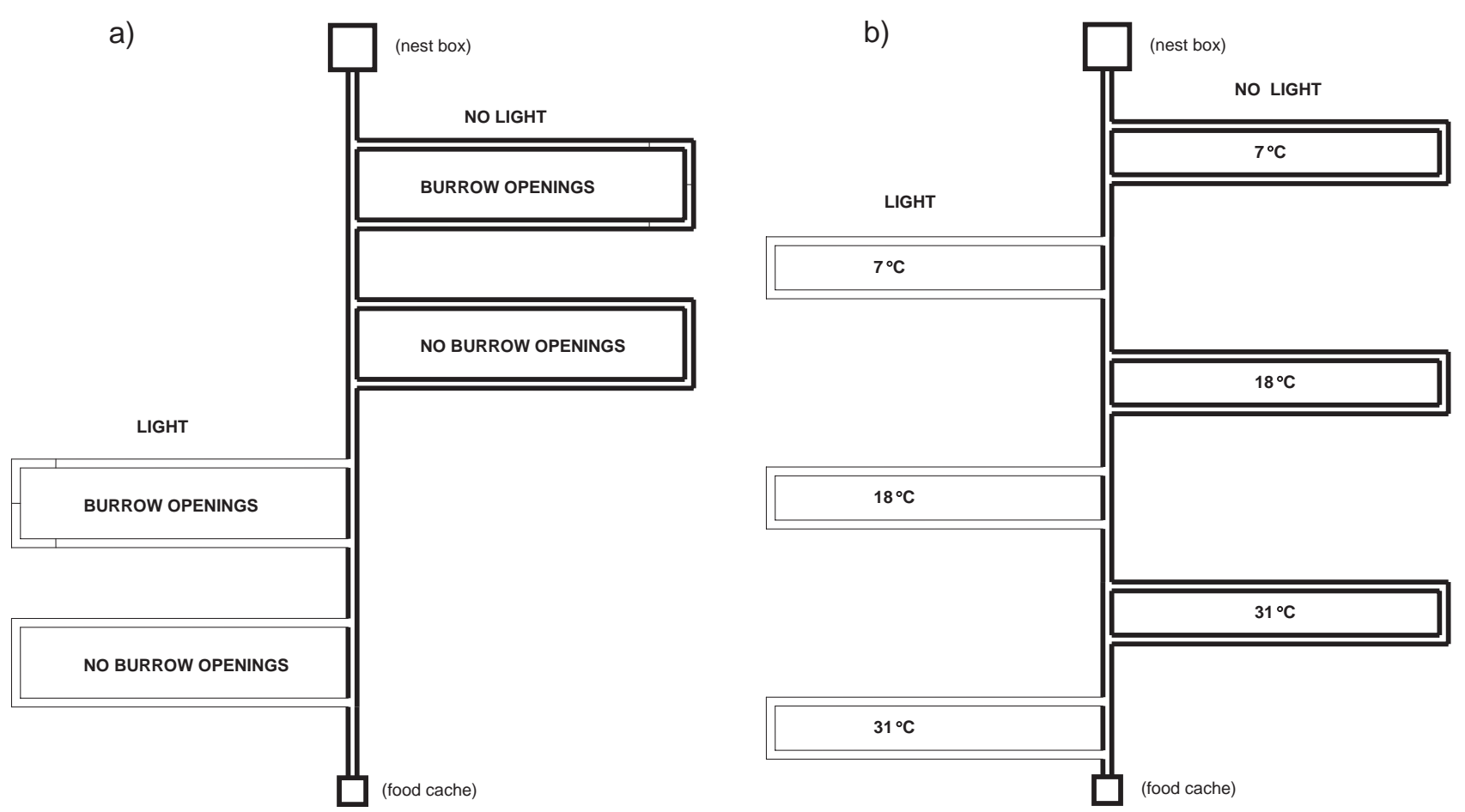

Fig. 1. Diagram of artificial burrow systems used to evaluate pocket gopher burrow plugging behavior within a two-by-two factorial of light and burrow openings (a; T. mazama), and a two-by-three factorial of light and temperature (b; T. talpoides). 
Ambient temperatures and the diel thermal-dynamic were measured $\left( \pm 1{ }^{\circ} \mathrm{C} ; 5-14 \mathrm{~cm}\right.$ burrow depth) using a mercury thermometer within burrows where pocket gophers $(n=5 ; T$. mazama) had been caught from August to September 1996 (Olympia, WA, USA). Similar burrow temperature measurements $\left( \pm 0.1^{\circ} \mathrm{C} ; 14-28 \mathrm{~cm}\right.$ burrow depth) were collected continuously for 3 days in July 1998 (one temperature recording each $2.4 \mathrm{~min}$ using StowAway temperature loggers, Onset Computer Corp., Pocasset, MA) within burrows where $T$. talpoides $(n=5)$ had been caught, near Logan, UT, USA. Since the average diel temperature within natural burrows was $20^{\circ} \mathrm{C}$ for T. mazama and $21^{\circ} \mathrm{C}$ for $T$. talpoides, we varied the thermal environment within our artificial systems (Fig. 1b) by approximately $50 \%\left(7{ }^{\circ} \mathrm{C}\right)$, $100 \%\left(18{ }^{\circ} \mathrm{C}\right)$, and $150 \%\left(31{ }^{\circ} \mathrm{C}\right)$ of burrow temperatures observed in the field (Fig. 2).

The individual plugging behavior of 20 pocket gophers (T. talpoides) was observed within an indoor, artificial burrow system. Light and temperature were varied independently in Experiment 2, with two levels of light (presence and absence), and three levels of temperature (7, 18 , and $\left.31{ }^{\circ} \mathrm{C}\right)$. The 7 and $31{ }^{\circ} \mathrm{C}$ treatments were housed within insulated boxes $(1.5 \times 0.8 \times 0.8 \mathrm{~m})$ to facilitate thermal maintenance during the $12-\mathrm{h}$ trial. Temperatures within each treatment were monitored and maintained $( \pm 3$ ${ }^{\circ} \mathrm{C}$ ), and food and water were available in the food cache throughout each trial. Light treatments were enabled by two incandescent $(100 \mathrm{~W})$ lights shone directly $(\mathrm{ca} .1 .5 \mathrm{~m})$ over light treatments. Light-by- $7{ }^{\circ} \mathrm{C}$ and light-by- $31{ }^{\circ} \mathrm{C}$ treat- ments were enabled by the penetration of these lights through transparent lids on the insulated boxes enclosing these system treatments. The dependent measure was again the length of all plugs in each burrow treatment, following the 12-h trial.

The ANOVA procedure of the SAS system was used to analyze the factorial, randomized block design of Experiment 2. Tukey post-hoc contrasts were again used to separate the means of significant $(P \leq 0.1)$ ANOVA effects (excluding animal replicates).

\section{Results and discussion}

\subsection{Experiment 1}

Gophers typically moved about the entire artificial burrow system during the first $2 \mathrm{~h}$ of the 12 -h trial. During this time, individual gophers frequently removed their previous plugs and created new plugs in an adjacent area within the artificial burrow. Plugs within the midline of the artificial burrow system (i.e., outside of system treatments) comprised $<4 \%$ of all plugs in this experiment. The distribution of plugs measured at the end of the 12-h trial was typically present (i.e., stabilized) by the third hour of each trial. Burrow plugs were typically found at the medial end of system treatments, thus isolating specific treatments from the midline of the system and remaining system treatments. We infer that gophers avoided unoccupied

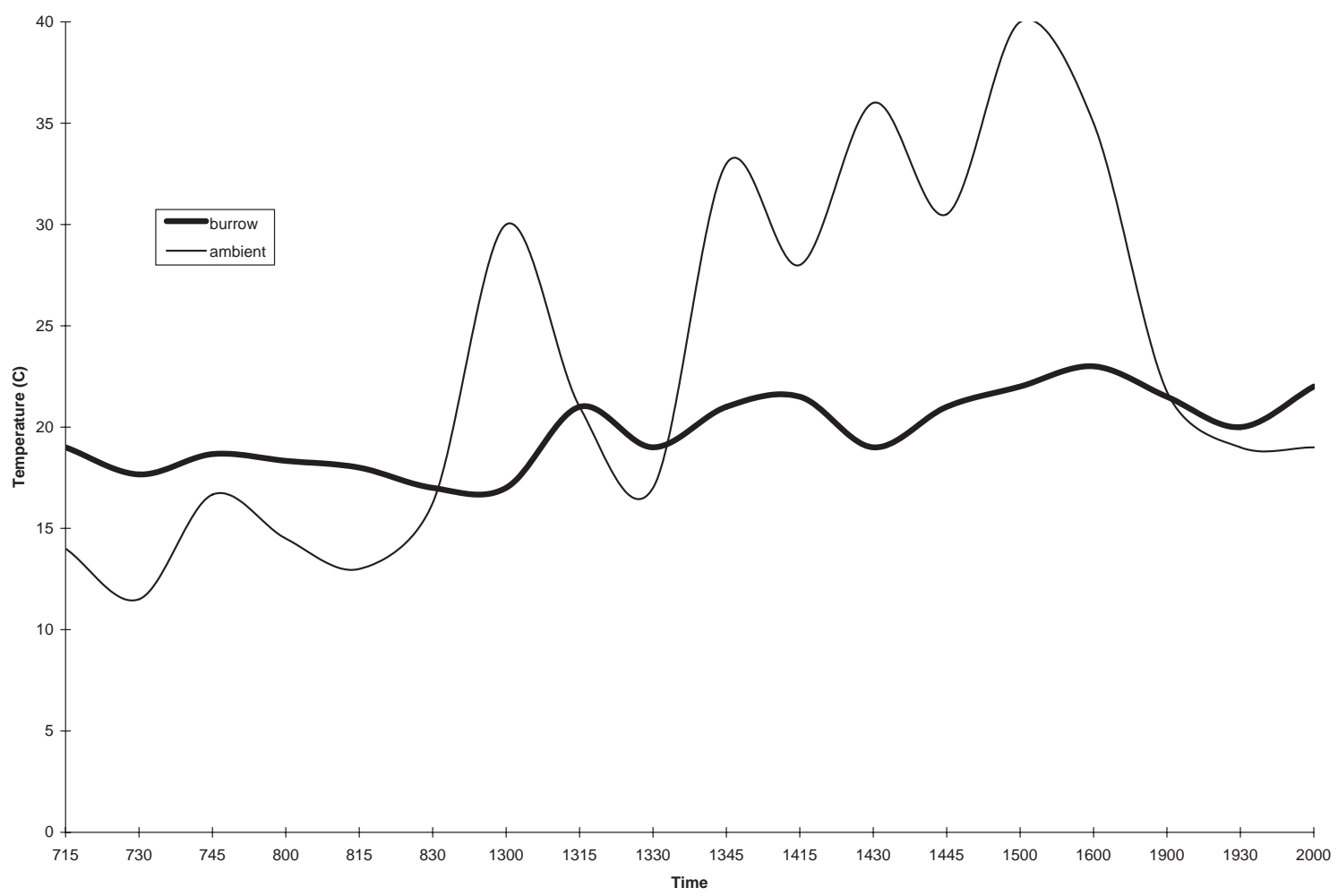

Fig. 2. Daily thermal dynamic of T. mazama burrow temperatures (5-14 $\mathrm{cm}$ below ground) and associated ambient (above-ground) temperatures from 14 August to 12 September 1996, Olympia, WA, USA. 
treatments beyond plugs established within the artificial burrow systems.

The presence of light induced plugging in this experiment $(F(1,66)=31.01, p=0.0001$; Fig. 3a). Burrow openings did not affect plugging behavior $(F(1,66)=0.79$, $p=0.3785)$ and no opening-by-light interaction was observed $(F(1,66)=0.26, p=0.6131)$. As the light cue used in this study covaried with ambient temperature, we varied light and ambient temperature independently in a second experiment to discern the relative effects of these cues on gopher plugging.

\subsection{Experiment 2}

Light and temperature both affected burrow plugging by gophers within this experiment (Fig. 3b). Light (independent of temperature) induced burrow plugging ( $F(1$, $90)=34.66, p=0.0001$ ). Temperature (independent of light) also affected plugging behavior $(F(2,90)=19.43$, $p=0.0001$ ). Gophers plugged more (Tukey $p<0.05$ ) within the $7{ }^{\circ} \mathrm{C}$ treatments than within the 31 and $18{ }^{\circ} \mathrm{C}$ environments. Although there was no statistical difference (Tukey $p>0.05$ ) between average plugging within the 31 and $18{ }^{\circ} \mathrm{C}$ treatments, gophers plugged most in the $7{ }^{\circ} \mathrm{C}$ treatment, and least in the $18{ }^{\circ} \mathrm{C}$ environment. No light-bytemperature interaction was observed in this experiment $(F(2,90)=0.55, p=0.5767)$.

These experiments illustrate the effect of light $(T$. mazama and T. talpoides) and thermal cues (T. talpoides) on pocket gopher behavior. In contrast to inferring the attractiveness of light due to its presence at successful trap sites, our experiments provided an artificial burrow system (i.e., four-, or six-sided "choice") within which animals could select or avoid system treatments. Thus, when given free access to light and no light, both Thomomys spp. consistently plugged, or avoided light treatments. Regard-
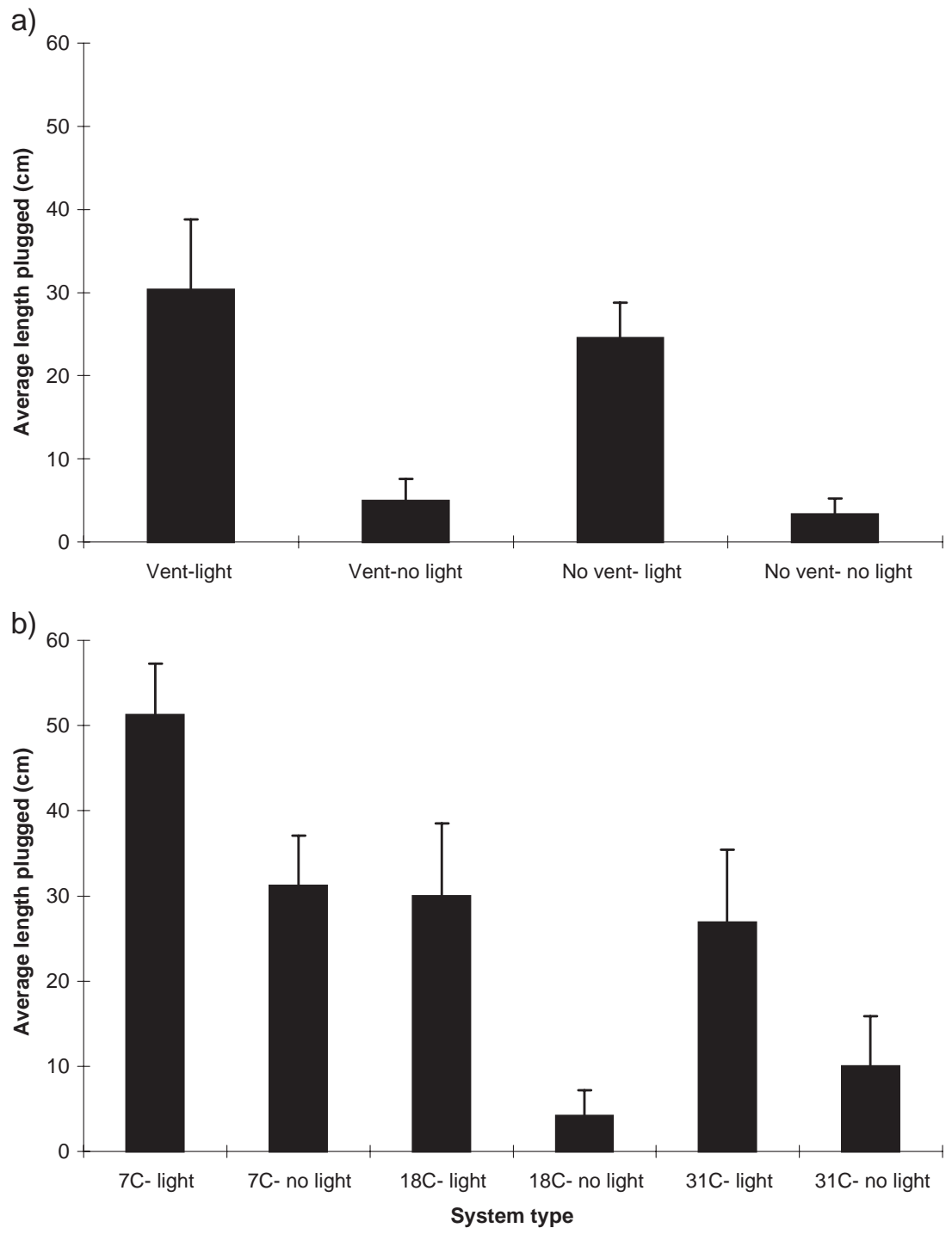

Fig. 3. Influence of burrow openings and light ( $; ; n=24$, . mazama), and temperature and light $(\mathrm{b} ; n=20$, T. talpoides $)$ on average $( \pm$ S.E. $)$ pocket gopher plugging behavior within an artificial burrow system. 
less of the relatively vestigial nature of pocket gopher visual organs, the presence of light can be used to affect behaviors such as burrow plugging and substrate transport.

Light intensity has been previously shown to affect the activity patterns of rodents [4]. Our results support the notion that "a behavioral response to increased light intensity suggests to us adaptation to reliable environmental cues" [3]. Light and darkness have been suggested to have no effect on pocket gopher activity [5] since Thomomys [6] and Geomys $[7,8]$ pocket gophers have been observed to be active during all hours of the day.

Air (i.e., burrow openings) and light may attract pocket gophers to particular places within a burrow for its maintenance [9]. Similarly, light may be an attractant for gopher trapping [10]. Related studies, however, have suggested that traps should be set within closed burrows to exclude light and air, and minimize trap rejection $[11,12]$. In a comparative investigation, no difference was observed in the success of covered (i.e., light and openings were excluded from burrows containing a set trap) and uncovered pocket gopher traps [13]. Our gopher-trapping efforts in the western United States (T. mazama in Washington, and T. talpoides in Utah) have been successful (averaging one capture per four or five set traps) using vegetation and soil plugs to close trap-containing burrows.

The response of pocket gophers to environmental stimuli must be interpreted in the context of below-ground sensory experience. Chemical and physical factors associated with burrow openings (e.g., odor, air pressure gradient, substrate texture, audible disturbances) continuously vary throughout the burrow milieu. In contrast, the presence of light within a burrow is always coincident with need for maintenance of the below-ground system. Thus, the presence of light (not burrow openings) is a reliable cue for maintenance of burrows occupied by pocket gophers.

Our results also indicate that T. talpoides plugged (i.e., avoided) portions of the artificial burrow that were maintained at relatively low temperatures, and selected areas maintained at $\geq 15{ }^{\circ} \mathrm{C}$. When the occupancy $G$. bursarius was observed within a thermally-stratified (12 to $39^{\circ} \mathrm{C}$ ), artificial burrow; the average temperature occupied was $27.2( \pm 0.1){ }^{\circ} \mathrm{C}$ [14]. Similar observations of $G$. bursarius, Pappogeomys castanops, and T. talpoides pocket gophers suggested that controlled light and temperature did not greatly affect the frequency or duration of diel movement patterns of these species within an artificial burrow system [15]. Environmental factors have been hypothesized to influence gopher tunneling activities that result in the formation of heaps and plugged surface-access tunnels [16]. These authors recommended that the clearing of artificially plugged tunnels by pocket gophers was negatively correlated with air temperature in the field. Thus, consideration of ambient light and temperature conditions may be useful for capturing Thomomys spp. and predicting their behavior.
Burrowing among pocket gophers can cost over 3000 times as much energy as that expended while traversing the same above-ground distance [17]. The metabolic cost of burrowing has been negatively correlated with genetic variation among pocket gophers; population differences in genetic variability are reflected in physiological fitness differences for burrowing [18]. The costly behavioral processes of food and habitat selection are reinforced by homeostasis. For example, the low variation in burrow temperatures relative to the terrestrial thermal dynamic (Fig. 2) is influenced by the insulating properties of the soil [7] and, thus, burrow plugging. We conclude that the presence of light and low ambient temperatures induce burrow maintenance, thus limiting adverse conditions to the internal and external environs of pocket gophers.

\section{Acknowledgments}

Drs. C.D. Cheney, M.W. Fall, J.R. Mason, J.A. Pfister, and G.A. Rasmussen reviewed a previous draft of this manuscript. This study was funded by the Berryman Institute for Wildlife Damage Management and the United States Department of Agriculture, Animal and Plant Health Inspection Service, Wildlife Services, National Wildlife Research Center (NWRC). The care and use of study subjects were approved by the Institutional Animal Care and Use Committee at NWRC and Utah State University.

\section{References}

[1] El-Hani A, Mason JR, Nolte DL, Schmidt RH. Flavor avoidance learning and its implications in reducing strychnine baiting hazards to nontarget animals. Physiol Behav 1998;64:585-9.

[2] Miller MA. Seasonal trends in burrowing of pocket gophers (Thomomys). J Mammal 1948;29:38-44.

[3] Reid VH, Hansen RM, Ward AL. Counting mounds and earth plugs to census mountain pocket gophers. J Wildl Manage 1966; $30: 327-34$

[4] Kramer KM, Birney EC. Effect of light intensity on activity patterns of Patagonian leaf-eared mice, Phyllotis xanthopygus. J Mammal 2001; $82: 535-44$

[5] Proulx G, Badry MJ, Cole PJ, Drescher RK, Kolenosky AJ, Pawlina IM. Summer activity of northern pocket gophers, Thomomys talpoides, in a simulated natural environment. Can Field-Nat 1995; 109:210-5

[6] Andersen DC, MacMahon JA. Population dynamics and bioenergetics of a fossorial herbivore: Thomomys talpoides (Rodentia: Geomyidae), in a spruce-fir sere. Ecol Monogr 1981;51:179-202.

[7] Cameron GN, Spencer SR, Eshelman BD, Williams LR, Gregory MJ. Activity and burrow structure of Attwater's pocket gopher (Geomys attwateri). J Mammal 1988;69:667-77.

[8] Vaughan TA, Hansen RM. Activity rhythm of the plains pocket gopher. J Mammal 1961;42:541-3.

[9] Crouch WE. Pocket-gopher control. USDA Farmers' Bull 1933;1709: $1-20$.

[10] Howard WE. A live trap for pocket gophers. J Mammal 1952;33: $61-5$.

[11] Dixon J. Control of the pocket gopher in California. Berkeley Agric Expt Stn Bull 1922;340:337-50. 
[12] Storer TI. Control of injurious rodents in California. Circ-Calif Agric Exp Stn 1942;79:3-66.

[13] Gamboa GJ. Effects of light air on the trapping response of the pocket gopher, Thomomys bottae (Geomyidae). J SW Nat 1975;19:444-6.

[14] Montgomery RD. The thermal ecology of the plains pocket gopher (Geomys bursarius) in east Texas, with consideration of evolutionary trends in Geomyidae. M.S.F. thesis, F. Stephen. Austin State Univ.; 1975. $115 \mathrm{p}$.

[15] Hickman GC. Effects of temperature and light on the locomotory activity of captive pocket gophers. Acta Theriol 1984;29:259-71.
[16] Cox GW, Hunt J. Relation of seasonal activity patterns of valley pocket gophers to temperature, rainfall, and food availability. J Mammal 1922;73:123-34.

[17] Vleck D. The energy cost of burrowing by the pocket gopher Thomomys bottae. Physiol Zool 1979;52:122-36.

[18] Hildner KK, Soule E. Relationship between the energetic cost of burrowing and genetic variability among populations of the pocket gopher, T. bottae: does physiological fitness correlate with genetic variability? J Exp Biol 2004;207:2221-7. 